\title{
Wood Charcoal and Ash to Maintain Seed Quality during Storage for Vegetable Seeds
}

\author{
Ebrima S. NJIE ${ }^{1}$ (D) Nurcan MEMiş ${ }^{2}$ (D) Cihat ÖZDAMAR ${ }^{2}$ \\ İbrahim DEMIR ${ }^{2}$
}

\author{
1 University of Gambia School of Agriculture and Environmental Sciences, 3530, Serrekunda, Gambia \\ 2 Ankara University Agriculture Faculty Horticulture Department, 06110, Ankara, Turkey
}

\author{
Article History \\ Received 17 April 2021 \\ Accepted 01 August 2021 \\ First Online 23 August 2021
}

\section{Corresponding Author}

E-mail: demir@agri.ankara.edu.tr

\section{Keywords \\ Cabbage \\ Carrot \\ Germination \\ Pepper \\ Seed vigour}

\begin{abstract}
This research was conducted to investigate the efficacy of charcoal and ash in maintaining the quality of lettuce, cabbage, onion, pepper and carrot seeds during storage. The seeds were stored over charcoal and ash at a seed/material ratio of $1: 1$ and stored at room temperature $\left(20^{\circ} \mathrm{C}\right)$ and at $35^{\circ} \mathrm{C}$ for 24 months. The control seeds were dried to between $5-6 \%$ seed moisture content and stored in hermetic packets at $-20^{\circ} \mathrm{C}$. Samples were collected from storage after $6,12,18$, and 24 months and subjected to a germination test and ageing test at $45^{\circ} \mathrm{C}$ for 72 hours using $72 \%$ saturated sodium chloride $(\mathrm{NaCl})$ solution. There was no difference between the seed viability for the controls and treatments after $6-12$ months at 20 and $35^{\circ} \mathrm{C}$ between the two storage methods. However, seed quality declined at 18 months and 24 months. This was seen in lettuce, onion and carrot seeds more than pepper and cabbage at both storage temperatures. Similarly, seed vigour also reduced with extended storage to 18 and 24 months. Results showed ash and charcoal can be used to maintain seed quality over 12 months even at $35^{\circ} \mathrm{C}$.
\end{abstract}

\section{Introduction}

The storage of high-quality seeds in controlled environments is important to ensure the availability of seeds to farmers for commercial and genepool conservation purposes. The seed moisture content and temperature play central roles in the maintenance of seed viability during storage (Roberts and Ellis, 1988; van Treuren et al., 2013; Hanson and Ellis, 2020). In tropical and sub-tropical environments, relative humidity and temperature often go up to $75 \%$ and $35^{\circ} \mathrm{C}$ during storage. When seeds are stored in non-hermetic media seeds absorb excess moisture beyond the safe level for optimum storage due to their hygroscopic nature (Dickie et al., 1990). Such environments also induce the proliferation of storage pathogens. Therefore, the ideal storage temperature and relative humidity for commercial seed storage is about $15-20^{\circ} \mathrm{C}$ and
$30-45 \%$ relative humidity for medium-term periods (6-18 months) (Demir and Ozcoban, 2007). However, maintaining such storage conditions is not easy in less developed countries due to high construction and electricity expenses. In this case, alternative storage structures may involve combinations of traditionally-available materials such as salt, lime, ash, charcoal, neem leaves, cow dung etc. to keep seeds dry during storage.

Wood charcoal and ash are cheap, easily available and affordable materials. Due to their hygroscopic nature, they can be used to maintain low seed moisture and prolong the shelf life of seeds (Karthikeyan et al., 2009; Oguntade and Adekunle, 2009; Oyekale et al., 2014; Ashok and Gowda, 2017). Wood charcoal (Karthikeyan et al., 2009; Oyekale et al., 2014; Ashok and Gowda, 2017) and wood-ash were used to keep seeds at low moisture content (Oguntade and Adekule, 
2009) and to deter without to the deleterious effects of storage pests (Wolfson et al. 1991; Gumaa and Elamin, 2015) during storage.

This work was designed to test the effect of charcoal and ash on quality during storage for cabbage, carrot, lettuce, pepper, and onion seeds at two different temperatures.

\section{Material and Method}

Seeds of onion (Allium cepa L. cv. Bereket), lettuce (Lactuca sativa L. Cv. Yedikule), cabbage (Brassica olarecea var. Capitata cv. Yalova-1), carrot (Daucus carota L. Maestro F1) and pepper (Capsicum annum L. cv. Yağlık-28) were purchased from seed companies.

The seed moisture content was determined according to ISTA (2006) rules.

\subsection{Storage of control seeds}

The control seeds in each species were stored at $-20^{\circ} \mathrm{C}$ with $5-6 \%$ seed moisture. These are the conditions in the seed gene bank for long-term storage. Seeds were dehydrated to $5-6 \%$ moisture content prior to storage. The seeds were weighed and dehydrated over silica gel in closed plastic boxes at the ratio of 1:5 at room temperature. The silica gel was regenerated every 48 hours at $105^{\circ} \mathrm{C}$ for 4 hours in a high temperature oven (Ellis et al., 1990 ) to dry the excess moisture absorbed from the seeds.

During the course of drying, the seeds were weighed twice a day to determine the decline in moisture content and determine the period when the seed moisture content will drop to 5-6\% (Demir and Ozcoban, 2007). The formula below was used to calculate the seed moisture content during the course of dehydration.

$$
\text { Seed m. c. }(\mathrm{g})=\frac{\text { Initial weight } \times(100-\text { initial seed m. c. })}{(100-\text { final seed } \mathrm{m} . \text { c. } \%)}
$$

Following seed dehydration to the desired moisture content, they were placed into aluminium foil packets. Four packets were prepared for each species and seven hundred seeds were placed in each packet. Then packets were placed in $-20^{\circ} \mathrm{C}$. One sample was removed from storage after 6,12 , 18 and 24 months. Of seeds in each packet, 200 were used to conduct the germination test, 200 for the vigour test and the remaining 300 seeds were used to determine the seed moisture content.

\subsection{Seed storage over wood-charcoal and wood-ash}

Wood charcoal was collected from local charcoal vendors and then ground and sieved into fine forms. The charcoal powder was then dehydrated at $105^{\circ} \mathrm{C}$ for 24 hours and placed into tightly-closed plastic bottles at room temperature before use. The wood ash (oak ash) was collected from a kebab restaurant and dehydrated to the same values as the charcoal. The dried ash and charcoal were placed in plastic aging boxes $(38 \times 10 \times 15 \mathrm{~cm})$ and the seeds were placed in meshed cloth bags for ease of handling. The material to seed ratio in the storage was 1:1 (w/w). Twenty plastic boxes (2 material $\times 5$ species $\times 2$ temperatures) were prepared with 10 at $35 \pm 3^{\circ} \mathrm{C}$ and the other 10 were stored at $20 \pm 3^{\circ} \mathrm{C}$. Germination test and accelerated ageing tests were conducted on each sample taken from storage after $6,12,18$ and 24 months for each species, drying method and storage temperature. The changes in seed moisture after every storage period for each sample were also calculated.

\subsection{Germination test}

Four replicates of fifty $(4 \times 50)$ seeds were used to determine germination percentage (GP). Prior to setting up the germination test, seeds were rehydrated for 24 hours at $100 \%$ relative humidity to eliminate potential negative impacts of imbibition damage on the seeds since they were very dry (Ellis et al., 1988).

The seeds were sown between moist germination papers with two papers below and one on top and placed in a germination chamber for 7 days for lettuce, 10 days for cabbage, 12 days for onion, and 14 days for carrot and pepper (ISTA 2006). At the end of the stipulated germination duration (as stated above), normal seedlings were evaluated and referred to as the germination percentage.

\subsection{Accelerated aging test}

To determine the vigour of the seeds after the various storage durations, 200 seeds from each variety were aged over a saturated salt solution for 72-hours duration.

Forty grams of sodium chloride $(\mathrm{NaCl}, 76 \%$ relative humidity) was dissolved in $100 \mathrm{~mL}$ of water as described by Jianhua and McDonald (1996) and stirred diligently. Forty millilitres $(40 \mathrm{ml})$ of saturated salt solution were placed in aging boxes $(11 \times 11 \times$ $5 \mathrm{~cm})$ with a steel wire mesh $(10 \times 10 \times 3 \mathrm{~cm})$ and the seeds were placed on top of the wire mesh.

The aging boxes with seeds in them were placed at room temperature $\left(25^{\circ} \mathrm{C}\right)$ for 24 hours in the dark to enable the seed moisture to equilibrate within the lots. The aging boxes were covered with a plastic film to prevent inflow or outflow of moisture and placed in an incubator at $45^{\circ} \mathrm{C}$ (Jianhua and McDonald, 1996). After 72 hours, the seeds were removed and subjected to a germination test, and normal seedling percentages were evaluated.

Results were analysed by using SPSS programme and the differences between drying methods in each sampling period were compared at $5 \%$ level. 


\section{Results and Discussion}

\subsection{Effects of storage on germination percentages}

Seed germination percentages were lower in control seeds compared to those stored in ash and charcoal for all five species at both temperatures throughout the storage period. However, the difference in each sampling period was not significant. Germination percentages of control seeds declined from 92 to $84 \%$ in lettuce, 92 to $87 \%$ in cabbage, 98 to $90 \%$ in onion, 98 to $87 \%$ in pepper, and 90 to $79 \%$ in carrot when seeds were stored at $20^{\circ} \mathrm{C}$ over 24 months (Table 1). The lowest mean germination percentages were seen in carrot at $77 \%$, while the highest was observed in pepper at $85 \%$. Mean germination percentages of seeds varied between 83 and $90 \%$ and 84 and $91 \%$ in charcoal and ash, respectively (Table 1). Seeds that were stored at $-20^{\circ} \mathrm{C}$ had a range between 85 and $93 \%$. The difference between the four storage time samples of control, charcoal and ash seeds was significant $(p<0.05)$ in three cases for cabbage and onion, two for lettuce, one for pepper and none for carrot seeds.

Storage at $35^{\circ} \mathrm{C}$ reduced seed germination faster than those stored at $20^{\circ} \mathrm{C}$. This was especially seen after 24 months of storage. At this sampling time, the lowest values were seen in ashstored lettuce and cabbage seeds at 61 and $67 \%$, respectively (Table 2). At this temperature, the difference between ash-stored and charcoal-stored seeds and control seeds started to become significant $(P<0.05)$ much earlier. The differences for all four samples of lettuce, onion and pepper were significant $(p<0.05)$ starting at 12 months and thereafter in carrot and cabbage seeds. The lowest mean germination percentages were seen in lettuce seeds at the final sampling as $72 \%$.

Carrot and cabbage seeds had $75 \%$ and $77 \%$ mean germination, respectively. Pepper seeds had mean germination of $84 \%$ after 24 months of storage. The difference between mean germination percentages of ash and charcoal storage at $35^{\circ} \mathrm{C}$ and control seeds were mostly about $4-8 \%$ and did not extend more than $10 \%$. The fastest germination loss was seen for lettuce which was stored in ash; seed germination declined from $92 \%$ before storage to $61 \%$ over 24 months.

Seed moisture and temperature are two main factors that affect seed longevity (Demir and Ozcoban, 2007; Hanson and Ellis, 2020). Seed moisture is the key factor to maintain longevity during storage. For small-sized vegetable seeds, such as lettuce, onion, and cabbage, moisture for long-term storage is supposed to be 5-7\% (Walters et al., 2005; Demir et al., 2016 a,b; Hay et al., 2019). As seed moisture increases seed longevity decreases (Hong et al., 2005). However, keeping seed moisture low at about $5-7 \%$ is not easy in tropical and sub-tropical regions where relative humidity remains high, i.e. $70 \%$. When seeds are stored under non-hermetic (air and water proof) conditions, seeds equilibrate to the high relative humidity and seed moisture increases. This is a common phenomenon when seeds are kept at room temperature in unpacked conditions. When high seed moisture is combined with high temperature during the summer season in sub-tropical or tropical environments, seed longevity is greatly affected (van Treuren et al., 2013; Bradford et al., 2018).

Medium term seed storage until the next production season comprises about 6-18 months.

Table 1. Germination percentage of seeds of five different species stored at $-20^{\circ} \mathrm{C}$ (Control) and over ash and charcoal for 24 months at $20^{\circ} \mathrm{C}$

\begin{tabular}{|c|c|c|c|c|c|c|c|}
\hline \multirow{2}{*}{ Species } & \multirow{2}{*}{ Treatment } & \multicolumn{5}{|c|}{ Storage duration (month) } & \multirow{2}{*}{ Mean } \\
\hline & & 0 & 6 & 12 & 18 & 24 & \\
\hline \multirow{4}{*}{ Lettuce } & Charcoal & 92 & $90^{a}$ & $89^{a}$ & $84^{\mathrm{ab}}$ & $78^{b}$ & 87 \\
\hline & Ash & 92 & $89^{a}$ & $86^{a}$ & $78^{b}$ & $74^{c}$ & 84 \\
\hline & Control & 92 & $91^{\mathrm{a}}$ & $88^{a}$ & $86^{\mathrm{a}}$ & $84^{a}$ & 88 \\
\hline & Mean & 92 & 90 & 88 & 83 & 79 & \\
\hline \multirow{4}{*}{ Cabbage } & Charcoal & 92 & $91^{\mathrm{a}}$ & $89^{b}$ & $84^{\mathrm{b}}$ & $80^{\mathrm{b}}$ & 87 \\
\hline & Ash & 92 & $90^{\mathrm{a}}$ & $89^{b}$ & $86^{\mathrm{b}}$ & $76^{c}$ & 87 \\
\hline & Control & 92 & $91^{\mathrm{a}}$ & $92^{\mathrm{a}}$ & $90^{\mathrm{a}}$ & $87^{a}$ & 90 \\
\hline & Mean & 92 & 91 & 90 & 87 & 81 & \\
\hline \multirow{4}{*}{ Onion } & Charcoal & 98 & $94^{\mathrm{a}}$ & $88^{b}$ & $85^{b}$ & $83^{b}$ & 89 \\
\hline & Ash & 98 & $95^{\mathrm{a}}$ & $89^{a b}$ & $84^{b}$ & $80^{b}$ & 89 \\
\hline & Control & 98 & $96^{a}$ & $93^{a}$ & $92^{a}$ & $90^{a}$ & 94 \\
\hline & Mean & 98 & 95 & 90 & 87 & 84 & \\
\hline \multirow{4}{*}{ Pepper } & Charcoal & 98 & $93^{b}$ & $89^{a}$ & $87^{a}$ & $85^{a}$ & 90 \\
\hline & Ash & 98 & $93^{b}$ & $90^{\mathrm{a}}$ & $88^{a}$ & $84^{a}$ & 91 \\
\hline & Control & 98 & $97^{a}$ & $92^{\mathrm{a}}$ & $89^{a}$ & $87^{a}$ & 93 \\
\hline & Mean & 98 & 94 & 90 & 88 & 85 & \\
\hline \multirow{4}{*}{ Carrot } & Charcoal & 90 & $89^{a}$ & $84^{a}$ & $80^{a}$ & $74^{a}$ & 83 \\
\hline & Ash & 90 & $89^{a}$ & $85^{a}$ & $80^{\mathrm{a}}$ & $79^{a}$ & 84 \\
\hline & Control & 90 & $88^{a}$ & $85^{\mathrm{a}}$ & $81^{\mathrm{a}}$ & $79^{a}$ & 85 \\
\hline & Mean & 90 & 89 & 85 & 80 & 77 & \\
\hline
\end{tabular}

Means with the same letters in the same sampling period and species were not significant $(p<0.05)$ 
Njie et al. / HortiS (2021) 38(2):94-100

Table 2. Germination percentage of seeds of five different species stored at $-20^{\circ} \mathrm{C}$ (Control) and over ash and charcoal for 24 months at $35^{\circ} \mathrm{C}$.

\begin{tabular}{|c|c|c|c|c|c|c|c|}
\hline \multirow{2}{*}{ Species } & \multirow{2}{*}{ Treatment } & \multicolumn{5}{|c|}{ Storage duration (month) } & \multirow{2}{*}{ Mean } \\
\hline & & 0 & 6 & 12 & 18 & 24 & \\
\hline \multirow{4}{*}{ Lettuce } & Charcoal & 92 & $88^{a}$ & $80^{\mathrm{b}}$ & $75^{b}$ & $70^{b}$ & 81 \\
\hline & Ash & 92 & $85^{b}$ & $81^{\mathrm{b}}$ & $73^{b}$ & $61^{c}$ & 78 \\
\hline & Control & 92 & $90^{\mathrm{a}}$ & $88^{a}$ & $86^{a}$ & $84^{\mathrm{a}}$ & 88 \\
\hline & Mean & 92 & 87 & 83 & 78 & 72 & \\
\hline \multirow{4}{*}{ Cabbage } & Charcoal & 92 & $90^{a}$ & $85^{b}$ & $83^{b}$ & $76^{\mathrm{b}}$ & 85 \\
\hline & Ash & 92 & $88^{a}$ & $84^{\mathrm{b}}$ & $80^{c}$ & $67^{c}$ & 82 \\
\hline & Control & 92 & $91^{a}$ & $92^{\mathrm{a}}$ & $90^{a}$ & $87^{a}$ & 90 \\
\hline & Mean & 92 & 90 & 87 & 84 & 77 & \\
\hline \multirow{4}{*}{ Onion } & Charcoal & 98 & $89^{b}$ & $84^{\mathrm{b}}$ & $82^{b}$ & $78^{b}$ & 86 \\
\hline & Ash & 98 & $90^{\mathrm{b}}$ & $87^{b}$ & $82^{b}$ & $74^{b}$ & 86 \\
\hline & Control & 98 & $96^{a}$ & $94^{a}$ & $92^{a}$ & $89^{a}$ & 94 \\
\hline & Mean & 98 & 93 & 88 & 85 & 80 & \\
\hline \multirow{4}{*}{ Pepper } & Charcoal & 98 & $91^{b}$ & $89^{b}$ & $83^{b}$ & $81^{b}$ & 88 \\
\hline & Ash & 98 & $90^{\mathrm{b}}$ & $87^{b}$ & $82^{b}$ & $74^{c}$ & 86 \\
\hline & Control & 98 & $96^{a}$ & $94^{a}$ & $92^{a}$ & $90^{\mathrm{a}}$ & 94 \\
\hline & Mean & 98 & 92 & 90 & 87 & 84 & \\
\hline \multirow{4}{*}{ Carrot } & Charcoal & 90 & $86^{a}$ & $80^{b}$ & $77^{b}$ & $71^{b}$ & 81 \\
\hline & Ash & 90 & $87^{a}$ & $86^{a b}$ & $77^{b}$ & $70^{\mathrm{b}}$ & 82 \\
\hline & Control & 90 & $89^{a}$ & $87^{a}$ & $85^{a}$ & $83^{a}$ & 87 \\
\hline & Mean & 90 & 87 & 84 & 80 & 75 & \\
\hline
\end{tabular}

Means with the same letters in the same sampling period and species were not significant $(p<0.05)$

Our experience showed that vegetable species can be stored with $5-7 \%$ seed moisture at about $20^{\circ} \mathrm{C}$ in hermetic conditions (Demir and Ozcoban, 2007; Demir et al., 2016 a, b) over that period. Such conditions are easy to meet in developed countries. However, low-income farmers and countries may not easily provide such conditions due to economic reasons. Under tropical climate conditions, elements of weather such temperature and relative humidity pose challenges to open air seed storage or in-situ or on-farm seed storage techniques which are common in developing countries (Ellis, 1991; Bradford, 2018). Carrot and lettuce seeds stored in paper bags under ambient conditions at $20^{\circ} \mathrm{C}$ and approximately $50 \%$ relative humidity exhibited great decline in seed germination during the storage period. The decline in germination percentage of lettuce seeds was faster (Nagel and Börner, 2010). Use of cheap and easily available materials can be an alternative method to keep seeds dry. There are number of various materials but ash and charcoal are widely used (Karthikeyan et al., 2009; Oyekale et al., 2014; Ashok and Gowda, 2017).

Our results also indicate that both can be used to maintain quality over 12 months in five species (Tables 1 and 2). Some species were found to lose seed quality earlier than others. Lettuce, onion and carrot appear to be more sensitive species than pepper and cabbage. Longevity changed according to species. Seeds of some species are inherently sensitive to longevity (Walters et al., 2005). Charcoal and ash keep seed moisture low during storage (Table 5). Our results are in agreement with the earlier findings that ash and charcoal keep seeds dry and can be used to maintain seed quality (Karthikeyan et al., 2009; Oguntade and Adekule, 2009; Oyekale et al., 2014; Ashok and Gowda, 2017).

\subsection{Effects of storage on seed vigour}

Seed vigour test results for seeds stored at $20^{\circ} \mathrm{C}$ indicated that the most resilient species is pepper. In this species, germination after ageing test was 81 and $83 \%$ after 24 months, while these values were 61 and $67 \%$ in lettuce, 68 and $66 \%$ in cabbage, 34 and $56 \%$ in onion, and $66 \%$ in carrot seeds for ash and charcoal storage, respectively (Table 3). Seed vigour of ash-stored onion seeds drastically reduced to 38 and $34 \%$ with storage to 18 and 24 months. Onion seeds lost seed vigour faster than other species. Mean onion seed germination percentage after 24 months was 57\%; this value was highest for pepper at $83 \%$. Pepper seeds lost vigour in germination of just about 10\% (93-83\%) from the beginning until the end of the storage, but this value went up to $17 \%$ in carrot, $19 \%$ in cabbage and lettuce, and $38 \%(95-57 \%)$ in onion seeds (Table 3).

Storage at $35^{\circ} \mathrm{C}$ more drastically reduced seed vigour germination. The minimum reduction was seen in the control seeds. Pepper seeds had the highest vigour germination at $77 \%$ for mean germination after 24 months of storage (Table 4). Onion and lettuce seeds had the lowest mean values at 45 and 54\%, respectively. Carrot and cabbage seeds had 59 and $67 \%$ after the same storage period.

Charcoal and ash onion seeds lost vigour by the end of storage. Vigour germination was reduced to 25 and $27 \%$. Such low values were not seen in any other species. In all species, vigour was lost at $35^{\circ} \mathrm{C}$ storage starting with the first ( 6 months) or second (12 months) samplings.

Seed vigour is a part of seed quality, which deals with seed emergence performance in field conditions and storability. Occurrence of seed 
Njie et al. / HortiS (2021) 38(2):94-100

Table 3. Germination of seeds of five species stored at $-20^{\circ} \mathrm{C}$ (control) and over ash and charcoal at $20^{\circ} \mathrm{C}$ after ageing test.

\begin{tabular}{|c|c|c|c|c|c|c|c|}
\hline \multirow{2}{*}{ Species } & \multirow{2}{*}{ Treatment } & \multicolumn{5}{|c|}{ Storage duration (month) Vigour (\%) } & \multirow{2}{*}{ Mean } \\
\hline & & 0 & 6 & 12 & 18 & 24 & \\
\hline \multirow{4}{*}{ Lettuce } & Charcoal & 88 & $87^{b}$ & $81^{b}$ & $77^{a}$ & $67^{b}$ & 80 \\
\hline & Ash & 88 & $86^{b}$ & $77^{c}$ & $70^{b}$ & $61^{c}$ & 76 \\
\hline & Control & 88 & $91^{\mathrm{a}}$ & $89^{a}$ & $84^{a}$ & $78^{a}$ & 86 \\
\hline & Mean & 88 & 88 & 82 & 77 & 69 & \\
\hline \multirow{4}{*}{ Cabbage } & Charcoal & 90 & $85^{b}$ & $78^{b}$ & $73^{b}$ & $66^{b}$ & 78 \\
\hline & Ash & 90 & $82^{b}$ & $78^{b}$ & $73^{b}$ & $68^{b}$ & 78 \\
\hline & Control & 90 & $89^{a}$ & $85^{a}$ & $83^{a}$ & $78^{a}$ & 85 \\
\hline & Mean & 90 & 85 & 80 & 76 & 71 & \\
\hline \multirow{4}{*}{ Onion } & Charcoal & 95 & $83^{b}$ & $74^{b}$ & $66^{b}$ & $56^{b}$ & 75 \\
\hline & Ash & 95 & $84^{b}$ & $67^{b}$ & $38^{c}$ & $34^{c}$ & 64 \\
\hline & Control & 95 & $94^{a}$ & $89^{a}$ & $86^{a}$ & $82^{\mathrm{a}}$ & 89 \\
\hline & Mean & 95 & 87 & 77 & 63 & 57 & \\
\hline \multirow{4}{*}{ Pepper } & Charcoal & 93 & $93^{a}$ & $85^{b}$ & $85^{a}$ & $83^{a}$ & 88 \\
\hline & Ash & 93 & $93^{a}$ & $88^{a}$ & $86^{a}$ & $81^{a}$ & 88 \\
\hline & Control & 93 & $91^{a}$ & $89^{a}$ & $87^{a}$ & $85^{a}$ & 89 \\
\hline & Mean & 93 & 92 & 86 & 86 & 83 & \\
\hline \multirow{4}{*}{ Carrot } & Charcoal & 82 & $77^{a}$ & $74^{a}$ & $69^{a}$ & $66^{a}$ & 74 \\
\hline & Ash & 82 & $77^{a}$ & $72^{\mathrm{a}}$ & $69^{a}$ & $66^{a}$ & 73 \\
\hline & Control & 82 & $81^{\mathrm{a}}$ & $75^{\mathrm{a}}$ & $70^{\mathrm{a}}$ & $64^{\mathrm{a}}$ & 74 \\
\hline & Mean & 82 & 78 & 74 & 69 & 65 & \\
\hline
\end{tabular}

Means with the same letters in the same sampling period and species were not significant $(p<0.05)$

Table 4. Germination of seeds of five species stored at $-20^{\circ} \mathrm{C}$ (control) and over ash and charcoal at $35^{\circ} \mathrm{C}$ after ageing test.

\begin{tabular}{|c|c|c|c|c|c|c|c|}
\hline \multirow{2}{*}{ Species } & \multirow{2}{*}{ Treatment } & \multicolumn{5}{|c|}{ Storage duration (month) Vigour (\%) } & \multirow{2}{*}{ Mean } \\
\hline & & 0 & 6 & 12 & 18 & 24 & \\
\hline \multirow{4}{*}{ Lettuce } & Charcoal & 88 & $76^{b}$ & $73^{b}$ & $66^{b}$ & $40^{\mathrm{b}}$ & 55 \\
\hline & Ash & 88 & $74^{b}$ & $73^{b}$ & $53^{c}$ & $43^{b}$ & 66 \\
\hline & Control & 88 & $91^{a}$ & $89^{a}$ & $84^{a}$ & $78^{\mathrm{a}}$ & 86 \\
\hline & Mean & 88 & 80 & 78 & 68 & 54 & \\
\hline \multirow{4}{*}{ Cabbage } & Charcoal & 90 & $79^{a}$ & $71^{\mathrm{c}}$ & $62^{c}$ & $60^{\mathrm{b}}$ & 72 \\
\hline & Ash & 90 & $78^{a}$ & $75^{b}$ & $70^{\mathrm{b}}$ & $62^{b}$ & 75 \\
\hline & Control & 90 & $89^{a}$ & $85^{\mathrm{a}}$ & $83^{a}$ & $78^{\mathrm{a}}$ & 85 \\
\hline & Mean & 90 & 82 & 77 & 72 & 67 & \\
\hline \multirow{4}{*}{ Onion } & Charcoal & 95 & $87^{a b}$ & $65^{b}$ & $40^{b}$ & $25^{\mathrm{b}}$ & 62 \\
\hline & Ash & 95 & $83^{b}$ & $61^{b}$ & $46^{b}$ & $27^{b}$ & 62 \\
\hline & Control & 95 & $91^{a}$ & $88^{a}$ & $86^{a}$ & $82^{a}$ & 88 \\
\hline & Mean & 95 & 87 & 71 & 57 & 45 & \\
\hline \multirow{4}{*}{ Pepper } & Charcoal & 93 & $88^{b}$ & $85^{b}$ & $79^{b}$ & $73^{b}$ & 83 \\
\hline & Ash & 93 & $89^{b}$ & $83^{a b}$ & $77^{\mathrm{b}}$ & $72^{\mathrm{b}}$ & 83 \\
\hline & Control & 93 & $91^{a}$ & $88^{a}$ & $86^{a}$ & $85^{a}$ & 89 \\
\hline & Mean & 93 & 89 & 85 & 81 & 77 & \\
\hline \multirow{4}{*}{ Carrot } & Charcoal & 82 & $74^{a}$ & $69^{b}$ & $65^{b}$ & $58^{a}$ & 70 \\
\hline & Ash & 82 & $75^{a}$ & $68^{b}$ & $65^{b}$ & $56^{a}$ & 69 \\
\hline & Control & 82 & $81^{a}$ & $76^{a}$ & $70^{\mathrm{a}}$ & $64^{a}$ & 75 \\
\hline & Mean & 82 & 77 & 71 & 67 & 59 & \\
\hline
\end{tabular}

Means with the same letters in the same sampling period and species were not significant $(p<0.05)$

vigour in general precedes seed germination. Accelerated ageing is a vigour test commonly used in a wide range of crop seeds (Demir and Mavi, 2007; Guloksuz and Demir, 2012).

Seed vigour values / germination after accelerated ageing test presented in Tables 3 and 4 showed that vigour loss occurs earlier than germination loss and accelerates as storage duration extends. Moreover, storage at higher temperature reduces seed vigour than storage at $20^{\circ} \mathrm{C}$. Seed vigour of species was higher in earlier storage periods, i.e. 6 and 12 months.
Our results showed that charcoal and ash storage not only preserves seed germination but also seed vigour and hence field emergence potential. This is in agreement with the findings of Karthikeyan et al. (2009).

\subsection{Changes in seed moisture during storage}

Seeds stored both charcoal and ash lost seed moisture gradually during the extended storage period. Seed moisture loss was slightly faster at $35^{\circ} \mathrm{C}$ compared to $20^{\circ} \mathrm{C}$. However, the difference 
Njie et al. / HortiS (2021) 38(2):94-100

Table 5. Changes in seed moisture contents of stored five vegetable species seeds in ash or charcoal during 24 months at $20^{\circ} \mathrm{C}$ and $35^{\circ} \mathrm{C}$ (italic number). Seed moisture in controls was set with silica gel and hermetic storage at $-20^{\circ} \mathrm{C}$.

\begin{tabular}{llccccc}
\hline \multirow{2}{*}{ Species } & \multirow{2}{*}{ Treatment } & 0 & 6 & 12 & 18 & 24 \\
\cline { 3 - 7 } Lettuce & Charcoal & 8.1 & $7.9 / 7.6$ & $7.8 / 7.0$ & $6.7 / 6.4$ & $5.9 / 4.8$ \\
& Ash & 8.1 & $7.8 / 7.3$ & $6.9 / 6.6$ & $6.1 / 6.1$ & $5.2 / 5.3$ \\
& Control & 6.2 & 6.2 & 6.2 & 6.2 & 6.2 \\
\hline \multirow{3}{*}{ Cabbage } & Charcoal & 8.4 & $7.9 / 7.7$ & $6.5 / 6.3$ & $5.3 / 5.4$ & $5.2 / 4.5$ \\
& Ash & 8.4 & $7.6 / 7.3$ & $6.6 / 6.1$ & $6.0 / 5.3$ & $5.2 / 5.2$ \\
& Control & 6.3 & 5.9 & 5.8 & 5.8 & 6.1 \\
\hline \multirow{3}{*}{ Onion } & Charcoal & 10.1 & $9.3 / 9.8$ & $8.8 / 8.3$ & $8.3 / 7.5$ & $7.3 / 6.1$ \\
& Ash & 10.1 & $9.4 / 9.4$ & $8.7 / 8.5$ & $8.1 / 7.2$ & $7.1 / 6.3$ \\
& Control & 6.0 & 5.7 & 5.4 & 5.3 & 5.3 \\
\hline \multirow{3}{*}{ Pepperyyyyyyy} & Charcoal & 8.3 & $7.6 / 7.8$ & $7.0 / 6.3$ & $6.5 / 5.5$ & $6.3 / 4.3$ \\
& Ash & 8.3 & $7.3 / 7.1$ & $6.9 / 6.4$ & $6.5 / 5.4$ & $6.2 / 4.4$ \\
& Control & 6.0 & 5.2 & 5.2 & 5.1 & 5.1 \\
\hline \multirow{3}{*}{ Carrot } & Charcoal & 8.1 & $7.3 / 7.6$ & $7.2 / 6.7$ & $6.6 / 6.7$ & $6.3 / 6.0$ \\
& Ash & 8.1 & $7.3 / 7.3$ & $7.2 / 7.1$ & $6.6 / 6.3$ & $6.3 / 5.7$ \\
& Control & 6.1 & 5.5 & 5.5 & 5.4 & 5.4 \\
\hline
\end{tabular}

was up to $1 \%$ in some species like pepper over 24 months. By the end of 24 months of storage, seed moisture ranged about $5 \pm 1 \%$ in all species except onion where seeds stored at $20^{\circ} \mathrm{C}$ had about $7 \%$ moisture. The highest initial seed moisture among all species was for onion at $10.1 \%$. Initial seed moisture in the other four species seeds was about $8.1-8.4 \%$. Control of seed moisture content remained between 5 and $6 \%$ throughout storage (Table 5).

One of the important issues with use of such materials is the proportion of seed and material. We used 1:1 in our work. This rate was beneficial for drying rice according to Hay et al. (2012). Our earlier experience also showed this proportion was appropriate. However, the use of higher material proportions may cause extreme drying in seeds during long-term storage and very low seed moisture $(<5 \%)$ which may be deleterious for seed quality through damaged cell structure (Demir and Ozcoban, 2007; Ashok and Gowda, 2017). In our work, seed moisture declined in some of the samples to below 5\% during extended storage periods (i.e. 24 months). Pepper and cabbage seed moisture was reduced to about $4.3-4.5 \%$ after 24 months of storage at $35^{\circ} \mathrm{C}$. We left seeds at $100 \%$ relative humidity before germination testing to avoid seed imbibition damage, which is a common procedure in seed gene banks (van Treuren et al., 2013). The control seeds in our study were stored at $-20^{\circ} \mathrm{C}$ with $5-7 \%$ seed moisture. This replicates seed gene bank conditions (Hay et al., 2019) without and are supposed to be the ideal conditions for very long-term storage.

Seeds stored with ash and charcoal germinated as well as those of control seeds during earlier stages of storage, i.e. 6 or 12 month (Tables 1 and 2). This was seen in seeds stored at both temperatures (Tables 1 and 2). Storage at $35^{\circ} \mathrm{C}$ reduced germination faster than for storage at $20^{\circ} \mathrm{C}$ during extended storage periods of 18 and 24 months (Table 2). This showed the negative effect of high temperature on longevity (Dickie et al., 1990).

\section{Conclusion}

The result of the present work showed that storage of lettuce, cabbage, pepper, onion and carrot seeds in charcoal and ash kept seeds dry and preserved germination and seed vigour over 12 months at 20 and $35^{\circ} \mathrm{C}$. When seed storage was extended to 18 and 24 months seed quality started to decline, particularly at $35^{\circ} \mathrm{C}$. This reduction was seen more for seed vigour than germination. Pepper appeared to be the most resilient species and lettuce and onion are the most sensitive ones. In conclusion, charcoal and ash storage has potential as alternative cheap and easy storage methods for low income farmers and small seed production enterprises.

\section{Acknowledgment}

We thank the presidency of Turkish relative communities for providing PhD scholarship to E. Njie.

\section{References}

Ashok, N.M.S., \& Gowda, B. (2017). Ultra-dry seed storage: A novel technology for enhancing seed longevity. International Journal of Chemical Studies, 5:1851-1857.

Bradford, K.J., Dahal, P., Asbrouck, J.V., Kunusoth, K., Bello, P., Thompson, J., \& Wu, F. (2018). The dry chain: Reducing postharvest losses and improving food safety in humid climates. Trends in Food Science \& Technology, 71:84-93.

Demir, I., \& Mavi, K. (2007). Controlled deterioration and accelerated aging tests to predict seedling emergence of watermelon under stressful conditions and longevity. Seed Science and Technology, 35:445459.

Demir, I., \& Ozcoban, M. (2007). Dry and ultra-dry storage of pepper, aubergine, winter squash, summer squash, bean, cowpea, okra, onion, leek, cabbage, radish, lettuce and melon seeds at $-20^{\circ} \mathrm{C}$ 
and $20^{\circ} \mathrm{C}$ over five years. Seed Science and Technology, 35:165-175.

Demir, I., Ozden, E., Kara, F., Hassanzadeh, M., \& Mavi, K. (2016a). Effects of Ambient storage temperature and seed moisture content on seed longevity of lettuce (Lactuca sativa). American Journal of Experimental Agriculture, 12:1-5.

Demir, I., Kara, F., Ozden, E., \& Hassanzadeh, M. (2016b). The effects of seed moisture content and regional storage temperature on the longevity of two onion cultivars. Acta Horticulturae, 1143:341-344.

Dickie, J.B., Ellis, R.H., Kraak, H.L., Ryder, K., \& Tompsett, P.B. (1990). Temperature and seed storage longevity. Annals of Botany, 65:197-204.

Ellis, R.H., Hong, T.D., \& Roberts, E H. (1988). A comparison of the low moisture content limit to the logarithmic relation between seed moisture and longevity in twelve species. Annals of Botany, 63:601611.

Ellis, R.H., Hong, T.D. Roberts, E.H., \& Tao, K.L. (1990). Low-moisture content limits to relations between seed longevity and moisture. Annals of Botany, 65:601-611.

Ellis, R.H. (1991). Longevity of seeds. HortScience, 26:1119-1125.

Guloksuz, T., \& Demir, I. (2012). Vigor tests in geranium, salvia, gazania and impatiens seed lots to estimate seedling emergence potential in modules. Propagation of Ornamental Plants, 12:133-138.

Hanson, J., \& Ellis, R.H. (2020). Progress and challenges in ex situ conservation of forega germplasm: grasses, herbaceous legumes and fodder trees. Plants, 9:1-16.

Gumaa, A.G.A., \& Elamin, A.E.H. (2015). Efficacy of groundnut oil, Wood Ash, Sand and some plants powders against Callosobruchus chinensis in cowpea seeds. Journal of Agricultural Science and Technology, 5:647-652.

Hay, F.R., Thavong, P., Taridno, P., \& Timple, S. (2012). Evaluation of zeolite seed 'Drying Beads ${ }^{\circledR}$ ' for drying rice seeds to low moisture content prior to long-term storage. Seed Science and Technology, 40:374-395.

Hay, F.R., Valdez, R., Lee, J.S., \& Santa Cruz, P.C. (2019). Seed longevity phenotyping: recommendations on research methodology. Journal of Experimental Botany, 70:425-434.

Hong, T.D., Ellis, R.H., Astley, D., Pinnegar, A.E., Groot, S.P.C., \& Kraak, H.L. (2005). Survival and vigour of ultra-dry seeds after ten years of hermetic storage. Seed Science and Technology, 33:449-460.

ISTA. (2006). International Rules for Seed Testing, International Seed Testing Association, Bassersdorf, Switzerland

Jianhua, Z., \& McDonald, M.B. (1996). The saturated salt accelerated aging test for small seeded crops. Seed Science and Technology, 25:123-131.

Karthikeyan, C., Veeraragathatham, D., Karpagam, D., \& Firdouse, S.A. (2009). Traditional storage practices. Indian Journal of Traditional Knowledge, 8:564-568.

Nagel, M., \& Börner, A. (2010). The longevity of crop seeds stored under ambient conditions. Seed Science Research, 20:1-12.

Oguntade, T.O., \& Adekunle, A.A. (2009). Preservation of seeds against fungi using wood-ash of some tropical forest trees in Nigeria. African Journal of Microbiology Research, 4:279-288.

Oyekale, K.O, Nwangburuka C.C., Denton, O.A., Adeyeye, J.A., Ayeni, S.E., \& Raheem, O.K. (2014). Predicting the longevity of sesame seeds under shortterm containerized storage with charcoal desiccant. American Journal of Experimental Agriculture, 4:111.

Roberts, E.H., \& Ellis, R.H. (1988). Water and seed survival. Annals of Botany, 63:39-52.

van Treuren, R., de Groot, E.C., \& van Hintum, T.J.L. (2013). Preservation of seed viability during 25 years of storage under standard gene bank conditions. Genetic Resources and Crop Evolution, 60:14071421.

Walters, C., Wheeler, L.M., \& Grotenhuis, J.M. (2005) Longevity of seeds in a genebank: species characteristics. Seed Science Research, 15:1-20.

Wolfson, J.L., Shade, R.E., Mentzer, P.E., \& Murdock, L.L. (1991). Efficacy of ash for controlling infestatıons of Callosobruchus maculatus (F.) (Coleoptera: Bruchidae) in stored cowpeas. Journal of Stored Products Research, 27:239-243. 